\title{
Forest stand biomass and NPP models sensitive to winter temperature and annual precipitation for Betula spp. in Eurasia
}

\author{
Vladimir Andreevich Usoltsev ${ }^{1,2}$, Walery Zukow ${ }^{3 *}$, Ivan Stepanovich Tsepordey ${ }^{2}$, \\ Viktor Petrovich Chasovskikh ${ }^{1}$
}

${ }^{1}$ Ural State Forest Engineering University, 620100 Yekaterinburg, Sibirskiy Trakt, 37, Russia

${ }^{2}$ Botanical Garden of Ural Branch of RAS, 620144 Yekaterinburg, 8 Marta str., 202a, Russia

${ }^{3}$ Faculty of Earth Sciences and Spatial Management, Nicolaus Copernicus University, Lwowska 1 str., 87-100 Torun, Poland,

*corresponding author e-mail: zukow@umk.pl

Received: 12 March 2020 / Accepted: 6 April 2020

\begin{abstract}
Forest ecosystems, as sinks of atmospheric carbon, play an important role in reducing $\mathrm{CO}_{2}$ emissions and preventing annual temperatures from rising. On the other hand, climate change entails changes in the structure and functions of all the biota, including forest cover. Therefore, we attempted to model Betula spp. ecosystem biomass and annual net primary production (NPP) ( $t$ ha $\left.{ }^{-1}\right) u^{-}$ ing the data from 650 forest stands for biomass, 245 for NPP and biomass, as well as climate data on the Trans-Eurasian hydrothermal gradients. The model involves regional peculiarities of age and morphology of the forests. It is found that the reaction of birch biomass and NPP structure on temperature and precipitation corresponds to the principle of limiting factors by Liebig-Shelford but in different proportions for different species. Since the minimum values of biomass and NPP occur in regions with minimum precipitation and minimum temperature, these two factors are limiting in terms of biomass and NPP of birches. The same phenomenon is typical for firs, partly typical for spruces and very differ for larches and pines. The development of such models for basic forestforming species grown in Eurasia will give possibility to predict any changes in the biological productivity of forest cover of Eurasia in relation to climate change.
\end{abstract}

Keywords: Betula spp. forests, forest biomass, biological productivity, net primary production, regression equations, mean January temperature, annual mean precipitation, the principle of limiting factors by Liebig-Shelford.

\section{Introduction}

At the United Nations climate summit in Paris in December 2015, 196 countries committed themselves to reducing $\mathrm{CO}_{2}$ emissions and preventing annual average temperatures from rising by more than $2^{\circ} \mathrm{C}$ by the end of the century. Forest ecosystems, as sinks of atmospheric carbon, play an important role in this perspective. In relation to global climate change, the scientific society needs to know quantitative information of forest biological productivity not only in statics but also in dynamics. But the latter is very problematic today. R.A. Houghton et al. (2009) write in "Geophysical Research Letters": "Our knowledge of the distribution and amount of terrestrial biomass is based almost entirely on ground measurements over an extremely small, and possibly biased sample, with many regions still unmeasured. Our understanding of changes in terrestrial biomass is even more rudimentary". Some analysis of methodically conditioned uncertainties related to experimental obtaining these data on sample plots is performed (Usoltsev, 2007b). 
The net primary productivity (NPP) of a forest ecosystem is defined as the rate at which solar energy is absorbed by the forest cover during photosynthesis (Odum, 1975), and it is determined by the same ecological independent variables as its biomass. In this time, it is very important to know a ratio of NPP to forest biomass, especially in terms of climate change. Nevertheless, H.E. Keeling and O.L. Phillips (2007) write: "Dynamic global vegetation model simulations imply that any increase in forest productivity driven by climate change will result in increases in biomass and therefore carbon storage. However, few studies have explored the strength and form of the relationship between forest productivity and biomass, whether in space or time". And there is a problem with forest biomass too: "An understanding of the relationship between forest biomass and climate is needed to predict the impacts of climate change on carbon stores. Biomass patterns have been characterized at geographically or climatically restricted scales, making it unclear if biomass is limited by climate in any general way at continental to global scales... Biomass is not strongly limited by climate in most forests so that forest biomass may not predictably respond to changes in mean climate" (Stegen et al., 2011).

Despite these uncertainties, it is now clearly established that temperature and precipitation are the most informative climatic factors that determine not only the radial growth of tree stems (Kharuk et al., 2015; He et al., 2019), but also forest stand NPP (Ni et al., 2001; Fang et al., 2016). The use of evapotranspiration as a combined index in the assessment of NPP is futile, since it explains only $24 \%$ of the NPP variability compared to $42 \%$, which provides the relation to mean annual precipitation, and compared to $31 \%$, which provides the relation to mean annual temperature (Ni et al., 2001). Numerous studies of stochastic relationships of stand NPP with temperature and precipitation have been carried out at a regional level without accounting for stand age and morphology (Ni et al., 2001; Fang et al., 2016), and at a global level without accounting for stand age and morphology and even without taking in mind tree species composition (Lieth, 1974; Nemani et al., 2003; Anderson et al., 2006; Huston \& Wolverton, 2009).

The influence of temperature and precipitation on the NPP change of tree species with accounting for stand age, morphology, and species composition has been studied at global or trans-continental level very seldom and in relation to coniferous species only (Usoltsev et al., 2019a). Hence, the purpose of this study was to develop a model of NPP change in birch (Betula spp.) stands as a reaction to change of mean January temperatures and sum of annual precipitation along to the Trans-Eurasian gradients.

Birch (Betula spp.) is a genus comprising about 120 species belonging to the Betulaceae C.A. Agardh. family, 40 of which are presented in Russia. There are several species in the common birch category from the section Albae
Rgl.: European silver birch (B. pendula Roth.), Downy birch (B. pubescens Ehrh.), Mountain birch (B. tortuosa Ldb.), Japanese white birch or Siberian silver birch ( $B$. platyphylla Suk.), etc. (Usoltsev, 2019).

The database compiled by V.A. Usoltsev (2010, 2013) makes it possible to perform this analysis of NPP (eventually for carbon sinks) at the trans-continental level. In the presence of the wide range of variation of hydrothermal indices in Eurasia, it seems promising to relate the NPP structure of birch stands described by a system of equations to two hydrothermal indices - mean January temperature and mean annual precipitation.

\section{Materials and methods}

The database on biomass of forest-forming species of Eurasia (Usoltsev, 2010, 2013) consisting of data published by a large number of authors was used in the modeling process of this study. From this database, 650 sampling sites with the biomass data of birch forest stands were selected. In most cases, sample trees were taken in a number from 5 to 10 copies on each of sample plots. Then samples were taken from each biomass component to determine the dry matter content (and for wood and bark of stems also to determine the basic density) and after drying the samples at the temperature of $80-100^{\circ} \mathrm{C}$, the results were recalculated for the whole tree. The quantity of each biomass component per 1 ha was determined by regression method. Nevertheless, some sampling procedures for estimating biomass of tree components differed between the studies, since they were performed by representatives of different scientific fields in forestry. The NPP in most cases was determined: of stems - by the ratio of its annual growth and volume, of roots - by the proportion of aboveground biomass and roots, of branches as a quotient of the division of branch biomass by crown age (Usoltsev, 2007a).

Not all biomass components are equally presented in the database: if the mass of stems above bark, branches and needles are determined on the all 650 plots, then the mass of the stem bark on 275, the mass of roots on 310 and the mass of understorey (the sum of grasses, brushes and ingrowth) on 320 plots. Data on birch biomass are distributed in Eurasia as follows: Western and Central Europe - 93, Russia - 360, Kazakhstan -58, China -130 and Japan -9 definitions. Data on birch NPP and biomass are distributed in Eurasia as follows: Western and Central Europe -22 , Russia - 80, Kazakhstan -13, China -127 and Japan -3 definitions (Table 1).

The matrix of biomass data representing individual components and forest stand characteristics was conjugated with the values of mean January temperature (Fig. 1) and precipitation (Fig. 2) taken from World Weather Maps (2007). 
Table 1. List of harvest biomass and NPP data in Betula spp. used for biomass and NPP modeling

\begin{tabular}{|c|c|c|}
\hline Species* of Betula & Country & $\begin{array}{c}\text { Number } \\
\text { of sampling sites }\end{array}$ \\
\hline \multicolumn{3}{|c|}{ Biomass } \\
\hline $\begin{array}{l}\text { Betula pendula Roth and } \\
\text { B. pubescens Ehrh. }\end{array}$ & $\begin{array}{l}\text { Russia, Ukraine, Kazakhstan, Great Britain, Belarus, Azerbaijan, } \\
\text { Finland, Japan, Sweden, Mongolia, Lithuania, Belgium, Norway, } \\
\text { France, Denmark (Greenland) }\end{array}$ & 500 \\
\hline B. utilis D.Don & China & 127 \\
\hline $\begin{array}{l}\text { B.pubescens var. pumila }(\mathrm{L} .) \\
\text { Govaerts (synonym B. tortuosa } \\
\text { Ledeb.) }\end{array}$ & Russia & 9 \\
\hline B. platyphylla Sukaczev & China, Russia, Japan & 6 \\
\hline B. ermanii Cham. & China, Japan & 4 \\
\hline B. maximowiziana Regel & Japan & 4 \\
\hline \multicolumn{2}{|l|}{ Total } & 650 \\
\hline \multicolumn{3}{|c|}{ NPP and biomass } \\
\hline $\begin{array}{l}\text { B. pendula Roth and } \\
\text { B. pubescens Ehrh. }\end{array}$ & $\begin{array}{l}\text { Russia, Kazakhstan, Great Britain, Belarus, Finland, Sweden, } \\
\text { Lithuania, Belgium, France }\end{array}$ & 115 \\
\hline B. utilis D.Don & China & 127 \\
\hline B. maximowicziana Regel & Japan & 3 \\
\hline \multicolumn{2}{|l|}{ Total } & 245 \\
\hline
\end{tabular}

" nomenclature according to World Flora Online http://www.worldfloraonline.org/

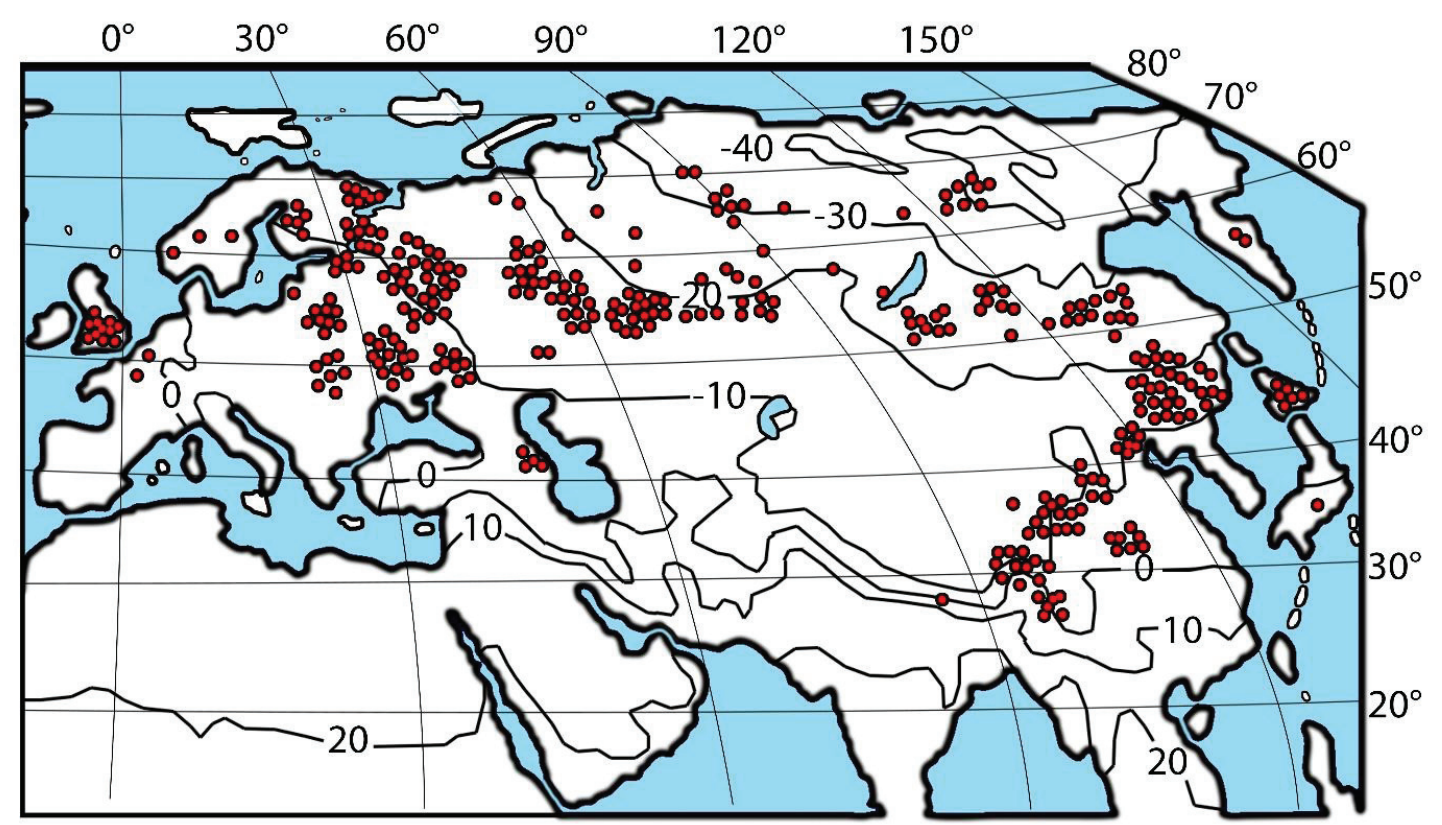

Figure 1. Distribution of 650 sample plots, where Betula trees have been harvested, on the map of the mean January temperature, ${ }^{\circ} \mathrm{C}$ (World Weather Maps, 2007; https://store.mapsofworld.com/image/cache/data/map_2014/currents-and-temperature-janenlarge-900x700.jpg) 


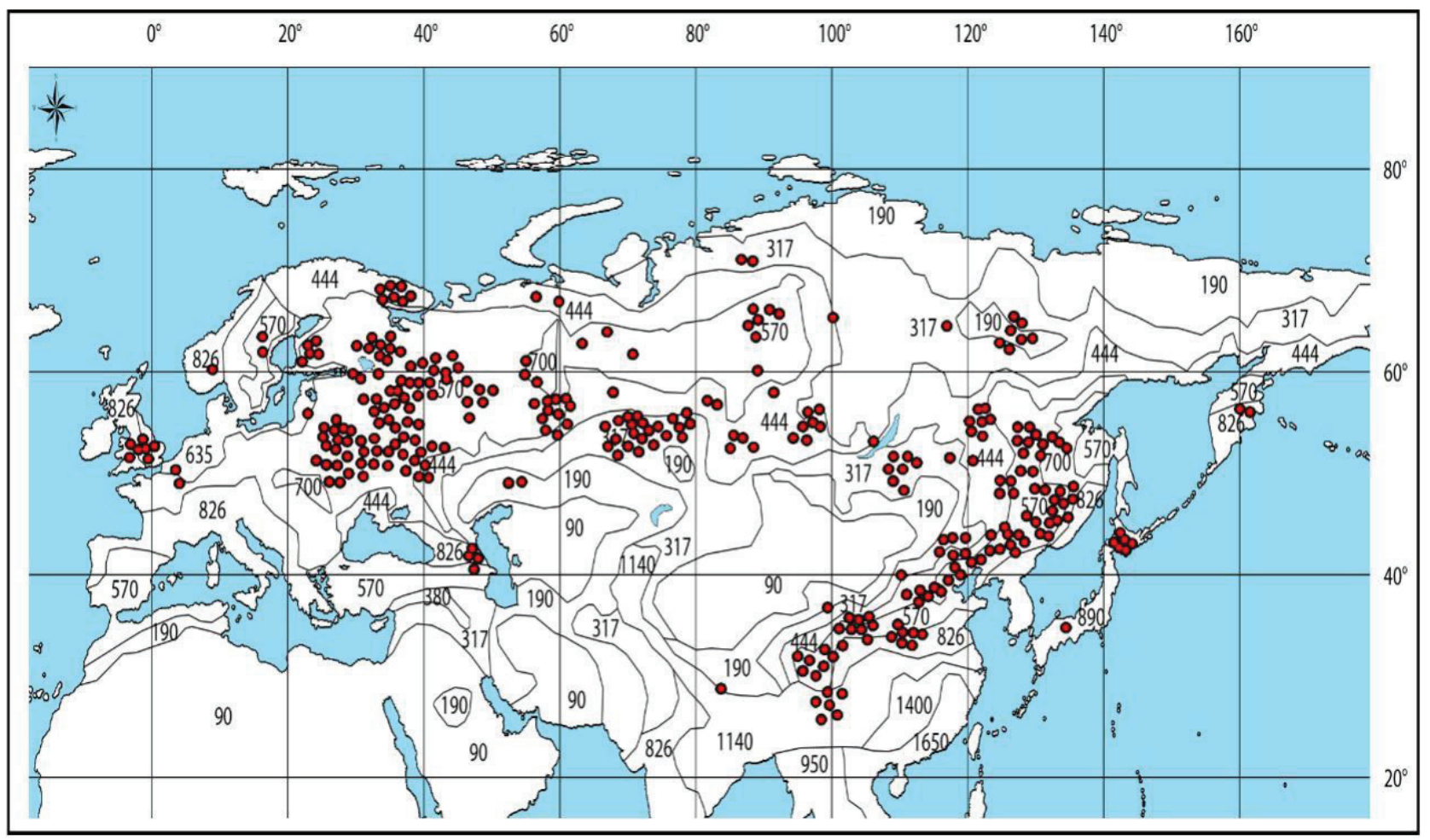

Figure 2. Distribution of 650 sample plots, where Betula trees have been harvested, on the map of the mean annual precipitation, mm (World Weather Maps, 2007; http://www.mapmost.com/world-precipitation-map/free-world-precipitation-map/)

It is generally known that the efficiency of environmental object modelling depends on the level of implementation of a meaningful analysis of empirical data, i.e. on the level of studying the change of impact factors over time and space. In relation to a single factor, this principle means identifying the most informative (active) range of its effects (Liepa, 1980) to find the optimal range within which the selected factor, ambiguous in its informativity, would explain the largest proportion of variability of the resulting variable. In our case, the schematic map of the isolines of mean January temperature, rather than that of the mean annual temperature, was used, as climate warming is most pronounced in the cold half of the year (Laing \& Binyamin, 2013; Felton et al., 2016). Obviously, taking the mean winter temperature as one of the independent variables, we get a more reliable dependence having the higher predictive ability.

Besides, to ensure the maximum stability of the model, each of the selected factors (independent variables) should be presented in the maximum range of its variation (Usoltsev, 2004). In our example, mean January temperatures range from $-40^{\circ} \mathrm{C}$ in the forest-tundra of the North-Eastern Siberia to $+10^{\circ} \mathrm{C}$ in the subtropics of China, and mean annual precipitation from $190 \mathrm{~mm}$ in the permafrost regions of North-Eastern Siberia and the steppe zone of Eurasia to $1140 \mathrm{~mm}$ in the territory of China.

When choosing the structure of the regression model, we adhered to the concept that there is only one definite variant of stand biomass and NPP structure corresponding to a given structure of a stand age and morphology (Usoltsev, 2007b). Since different biomass components are presented in the available databases in different ratios, the dependencies of the less represented component on the more represented one are calculated, for example, the total NPP on the aboveground one (Gower et al., 2001), or studying and modeling different root: shoot ratios (Levy et al., 2004; Wang et al., 2008).

As it was shown in Table 1, the NPP and biomass data of birches is almost three times smaller compared to their biomass only. Therefore, we included in our model the dependence of NPP on biomass. Since we need to disclose the influence of climate variables on the NPP: biomass ratio, we need to eliminate as much as possible the biases caused by regional features of the age and morphological structure of birch stands. The influence of climate variables affects not only the biomass : NPP ratio, but also the morphological structure of stands (number of trees per ha, site index, volume stock), and this influence of morpho- 
logical structure is consistently superimposed on the biomass : NPP ratio, as well as the biologically conditioned influence of the stand age (Gower et al., 1996; Magnani et al., 2000). To implement such an algorithm, we applied the method of recursive relations (Draper \& Smith, 1966), i.e. a chain of equations in which a dependent variable of a previous equation is included in a subsequent equation as one of its independent variables. The regression coefficients of multiple regression equations (1), (2), (3) and (4) are calculated using the Statgraphics software (see http:// www.statgraphics.com/for more information).

\section{Results}

This sequence is represented by the common model to be calculated:

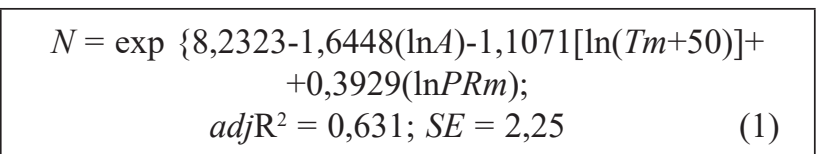

\begin{tabular}{c}
$\downarrow$ \\
$V=\exp \{-0,0174+0,8703(\ln A)-$ \\
$0,3795(\ln N)+0,1259(\ln A)(\ln N)+0,4301[\ln (T m+50)]+$ \\
$+0,0281(\ln P R m) ; \operatorname{adj} R^{2}=0,615 ; S E=1,68 \quad(2)$ \\
\hline
\end{tabular}

\section{$\downarrow$}

\begin{tabular}{c}
$P i=\exp \left\{\mathrm{a}_{0}+\mathrm{a}_{1}(\ln A)+\mathrm{a}_{2}(\ln V)+\mathrm{a}_{3}(\ln N)+\right.$ \\
$\left.+\mathrm{a}_{4}(\ln A)(\ln N)+\mathrm{a}_{5}[\ln (T m+50)]+\mathrm{a}_{6}(\ln P R m)\right\}$ \\
$\downarrow$ \\
\hline$Z i=\exp \left\{\mathrm{a}_{0}+\mathrm{a}_{1}(\ln A)+\mathrm{a}_{2}(\ln P i)+\right.$ \\
$\left.+\mathrm{a}_{3}[\ln (T m+50)]+\mathrm{a}_{4}(\ln P R m)\right\}$
\end{tabular}

In equations (1)-(4): $P_{i}$ - biomass of $i$-th component, t/ha; $Z_{i}$ - annual NPP of $i$-th component, t/ha; $A-$ stand age, yrs; $V$ - stem volume, $\mathrm{m}^{3} / \mathrm{ha} ; N$ - tree density, 1000/ ha; $i$ - index of biomass component: total wood storey $(\mathrm{t})$, understorey including the sum of brushes, undergrowth, and living grass cover (u), aboveground wood storey (a), underground wood storey, or roots (r), stem over the bark (s), foliage (f), and branches (b); PRm - mean annual precipitation, мM; Tm - mean January temperature, ${ }^{\circ} \mathrm{C}$. Because mean January temperature in northern part of Eurasia has negative values, corresponding independent variable is modified to the form $(\mathrm{Tm}+50)$.

The initial structure of the model included the main mass-forming indices of stands - age, stem volume, tree density, mean diameter and mean height. Mean diameter as correlated with tree density and mean height as correlated with age, were excluded in the process of the regression analysis as not statistically significant. The synergism $(\ln A) \cdot(\ln N)$ was introduced in the model to account for the decrease in the tree density with age and its effect on the stand biomass. The final structure of the model included only those mass-forming indices that were statistically significant for all biomass components. After correcting on logarithmic transformation by G.L. Baskerville (1972), the calculated equations (3) and (4) for the different components of the phytocenosis biomass and NPP are presented in Tables 2 and 3. All the regression coefficients for numerical variables in equations (1)-(4) are significant at the level of probability $P_{0.95}$ or higher, and the equations are adequate to harvest data.

The results of tabulating the model in the sequence of equations (1), (2), (3) and (4) present the rather cumbersome table. We took from it the values of the component composition of biomass and NPP of birch forests for the age of 50 years and built 3D-graphs of their dependence upon temperature and precipitation (Fig. 3 and 4).

\section{Discussion}

It is well known the Liebig's law of the minimum (1840), according to which a growth rate depends on the factor that is at the minimum in relation to its needs. Although J. Liebig, followed by J. Esslen (1905), had shown that a limiting factor can be not only a lack, but also an excess of such factors as light, heat and moisture (a lot of "good" is also "not good"), nevertheless, he focused his attention mainly on the effect of the minimum of chemicals (oxygen, phosphorus, boron, etc.), and as a result of that, this phenomenon was established in science as the law (principle) of the minimum by Liebig.

The idea of the limiting influence of the maximum on a par with the minimum was developed by V. Shelford (1913), who extended the limiting principle to any environmental factors and became known as the author of Shelford's law of tolerance. W.P. Taylor (1934) followed the same concept. Later A.A. Molchanov (1971) interpreted the limiting principle in relation to forest ecosystems as an "extended concept of limiting factors", according to which "any state approaching or exceeding the limit of resistance for any organism and groups of interest can be considered as a limiting factor" (p. 271). Recently, this phenomenon has become widespread as the principle of limiting factors by Liebig-Shelford (Rozenberg et al., 2016).

The reaction of birch biomass (Fig. 3) and NPP (Fig. 4) structure on temperature and precipitation corresponds to the principle by Liebig-Shelford: since the minimum values of biomass and NPP occur in regions with minimum precipitation $(200 \mathrm{~mm})$ and minimum temperature $\left(-40^{\circ} \mathrm{C}\right)$, these two factors are limiting in relation to biomass and NPP, and the same phenomenon is typical for firs (Usoltsev et al., 2019b). 
Table 2. Characteristics of biomass equations (3)

\begin{tabular}{|c|c|c|c|c|c|c|c|c|c|}
\hline $\begin{array}{c}\text { Biomass } \\
\text { components }\end{array}$ & \multicolumn{7}{|c|}{ Regression coefficients of equations (3) } & $\operatorname{adj} R^{2}$ a & $S E^{\mathrm{b}}$ \\
\hline$P t$ & 5.8057 & $A^{-0.0345}$ & $V^{0.7813}$ & $N^{-0.3137}$ & $A^{0.0795 \ln N}$ & $(T m+50)^{-0.0481}$ & $P R m^{-0.0798}$ & 0.943 & 1.18 \\
\hline$P u$ & 0.0052 & $A^{0.3668}$ & $V^{-0.0474}$ & $N^{-0.2501}$ & $A^{0.0694 \ln N}$ & $(T m+50)^{0.6425}$ & $P R m^{0.5034}$ & 0.121 & 2.33 \\
\hline$P a$ & 1.2499 & $A^{-0.0106}$ & $V^{0.9028}$ & $N^{-0.0162}$ & $A^{-0.0008 \ln N}$ & $(T m+50)^{0.0099}$ & $P R m^{-0.0276}$ & 0.975 & 1.14 \\
\hline $\operatorname{Pr}$ & 4.9132 & $A^{0.0929}$ & $V^{0.5196}$ & $N^{-0.4772}$ & $A^{0.1279 \ln N}$ & $(T m+50)^{-0.0780}$ & $P R m^{-0.1387}$ & 0.633 & 1.50 \\
\hline Ps & 0.8408 & $A^{-0.0553}$ & $V^{0.9929}$ & $N^{-0.0804}$ & $A^{0.0196 \ln N}$ & $(T m+50)^{-0.0630}$ & $P R m^{0.0016}$ & 0.980 & 1.14 \\
\hline$P f$ & 0.1388 & $A^{0.0251}$ & $V^{0.5438}$ & $N^{0.2360}$ & $A^{-0.0355 \ln N}$ & $(T m+50)^{0.3562}$ & $P R m^{-0.1479}$ & 0.486 & 1.57 \\
\hline $\mathrm{Pb}$ & 0.6307 & $A^{0.1424}$ & $V^{0.6278}$ & $N^{0.0190}$ & $A^{-0.0366 \ln N}$ & $(T m+50)^{0.3591}$ & $P R m^{-0.3073}$ & 0.780 & 1.45 \\
\hline
\end{tabular}

${ }^{a}$ adj $R^{2}$ - determination coefficient adjusted for the number of variables;

${ }^{\mathrm{b}} S E$ - standard error of the equation in the original dimension $P i(\mathrm{t} / \mathrm{ha})$.

Table 3. Characteristics of NPP equations (4)

\begin{tabular}{|c|c|c|c|c|c|c|c|}
\hline $\begin{array}{c}\text { NPP } \\
\text { components }\end{array}$ & \multicolumn{5}{|c|}{ Regression coefficients of equations (4) } & \multirow{2}{*}{$\begin{array}{c}\boldsymbol{a d j}^{2} \\
0.930\end{array}$} & \multirow{2}{*}{$\begin{array}{c}S E \\
1.21\end{array}$} \\
\hline$Z t$ & 0.0966 & $A^{-0.5699}$ & $P t^{0.9245}$ & $(T m+50)^{0.0335}$ & $P R m^{0.3674}$ & & \\
\hline$Z u$ & 0.1954 & $A^{-0.1913}$ & $P u^{0.8918}$ & $(T m+50)^{0.1201}$ & $P R m^{0.1819}$ & 0.652 & 1.53 \\
\hline$Z a$ & 0.4222 & $A^{-0.5698}$ & $\mathrm{~Pa}^{0.7890}$ & $(T m+50)^{0.1422}$ & $P R m^{0.1713}$ & 0.820 & 1.34 \\
\hline$Z r$ & 0.1895 & $A^{-0.7422}$ & $\operatorname{Pr} 0.9875$ & $(T m+50)^{0.0462}$ & $P R m^{0.2296}$ & 0.916 & 1.24 \\
\hline$Z s$ & 0.0971 & $A^{-0.8745}$ & $P_{S}{ }^{0.9038}$ & $(T m+50)^{0.3478}$ & $P R m^{0.2786}$ & 0.859 & 1.40 \\
\hline$Z f$ & 0.9294 & $A^{-0.0431}$ & $P f^{0.9832}$ & $(T m+50)^{-0.0379}$ & $P R m^{0.0555}$ & 0.954 & 1.17 \\
\hline$Z b$ & 0.0792 & $A^{-0.8302}$ & $P b^{0.7365}$ & $(T m+50)^{0.2133}$ & $P R m^{0.4576}$ & 0.704 & 1.47 \\
\hline
\end{tabular}

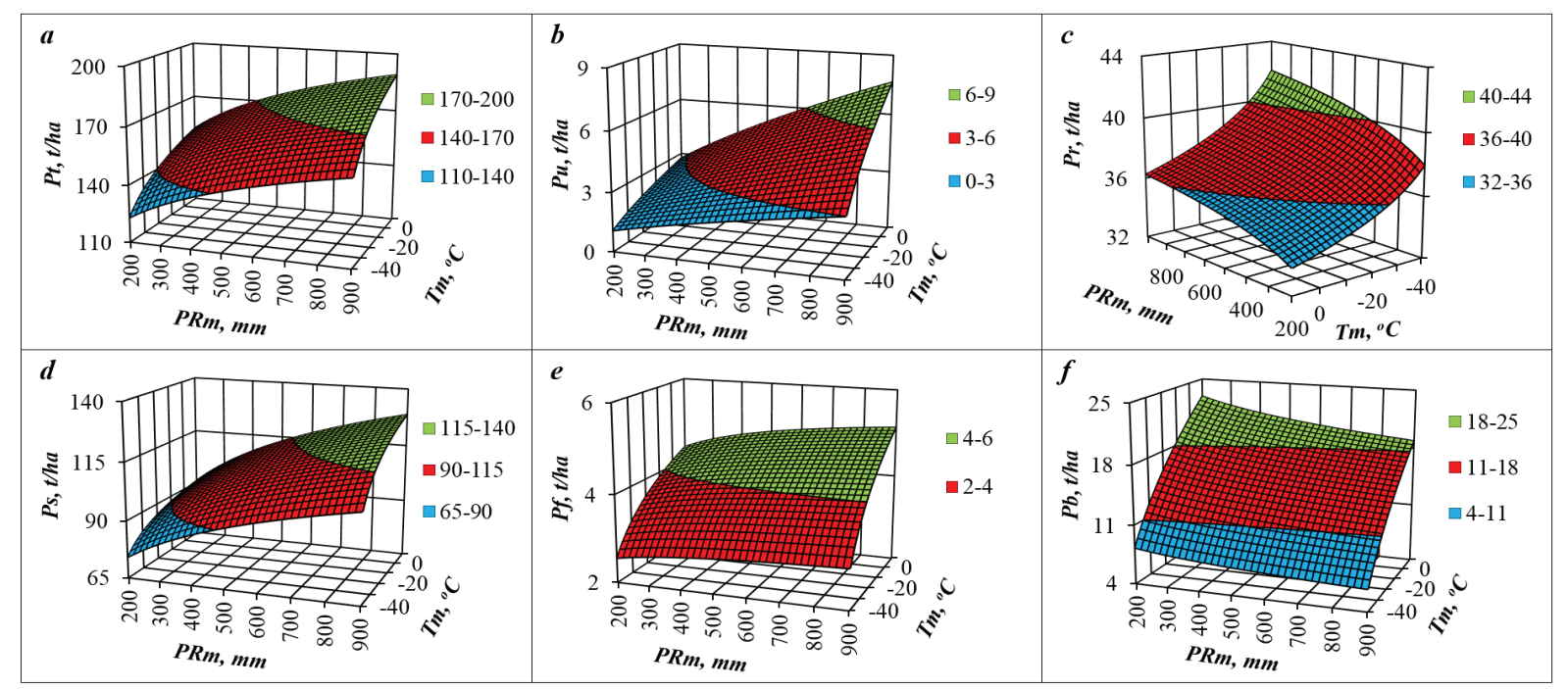

Figure 3. Dependence of birch phytocenoses biomass of Eurasia upon the mean January temperature (Tm) and mean annual precipitation $(P R m)$. Designations: $P t, P u, P r, P s, P f, P b$ are respectively biomass of: total wood storey $(a)$, understorey $(b)$, underground storey (roots) $(c)$, stems (wood and bark) $(d)$, foliage $(e)$ and branches (f), t/ha 


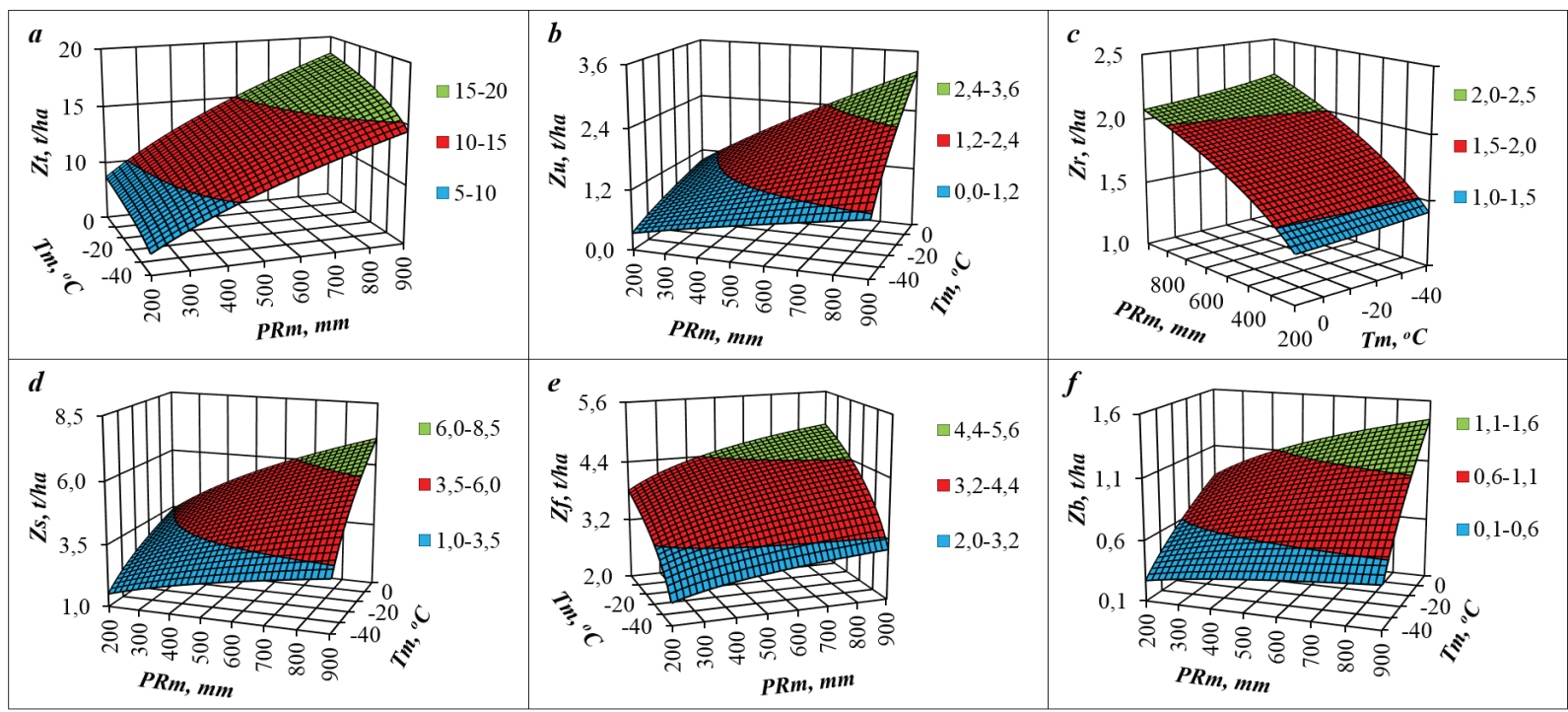

Figure 4. Dependence of birch phytocenoses NPP of Eurasia upon the mean January temperature $(T m)$ and mean annual precipitation $(P R m)$. Designations see Figure 3

Reaction of spruces (Usoltsev et al., 2019c) to the climate variables is similar to the response of birches only in part: if in warm regions $\left(+10^{\circ} \mathrm{C}\right)$ with increasing precipitation, the productivity of spruce stands increases, then in cold regions it is minimal regardless of the level of precipitation, i.e. the limiting factor for spruce productivity is only the temperature.

Another character of differences of birch biomass and NPP is with two-needled pine ones (Usoltsev et al., 2019a): in the conditions of warm shortage with sufficient moisture supply (Northern Siberia' regions), an air temperature increase leads to an increase in the productivity of stands of pines, but an increase in precipitation leads to its decrease. In conditions of moisture deficiency with sufficient warm supply (steppe part of Central Asia), the temperature increase causes a decrease in productivity, and the increase in precipitation, on the contrary, its increase. This demonstrates the confirmation of the limiting factor principle: in conditions of a lack of moisture or heat, any increase in precipitation or temperature exacerbates the limitation, and biomass decreases, and vice versa.

Genus Larix spp. as an unique deciduous tree in the evergreen world (Gower \& Richards, 1990) is consistent with birches, spruces and firs on the reaction of biomass and NPP to temperature, but due to precipitation, the biomass of all its components decreases (Usoltsev et al., 2019d; Usoltsev et al., 2020). Thus, for larch biomass and NPP, limiting factors are lack of heat and excess of moisture.

All these differences can be explained by speciesspecific hydrothermal optima of birches, pines, spruces, larches and firs. S. Gower and J. Richards (1990) consid- ered the widespread occurrence of deciduous larches in the evergreen world of conifers as a paradox and "an intriguing puzzle given the concept that the evergreen habit is more advantageous in harsh environment", for example, on permafrost sites. T. Givnish (2002), in his analysis of adaptation features of coniferous and deciduous species, expands the field of paradoxes and considers even the triple paradox involving dominance by: "(1) evergreens in highly seasonal, boreal forests, (2) deciduous larch in many nutrient-poor peatlands, and (3) evergreen leaf-exchangers in nutrient-poor subtropical forests, even though they shed their leaves just as frequently as deciduous species". To these paradoxes one can add the contradictory relations of assimilation biomass and stem growth in European Russia and in the Siberian northern taiga, revealed for the total forest cover (Lapenis et al., 2005) as well as the contradictions of zonal foliage efficiency in coniferous and deciduous species (Usoltsev, 2017). The contradictions revealed by us in adaptation abilities of birches, larch, pines, spruces and firs together with the mentioned paradoxes confirm the known thesis according to which the solution of each new problem and the corresponding removal of the associated uncertainty generates several new problems and uncertainties.

\section{Conclusion}

Thus, the first attempt of modeling changes in component composition of biomass and NPP of birch communities on the Trans-Eurasian gradients of temperature and rainfall, 
involving regional peculiarities of age and morphology of the forests, is fulfilled. It is found that the reaction of birch biomass and NPP structure on temperature and precipitation corresponds to the principle by Liebig-Shelford: since the minimum values of biomass and NPP occur in regions with minimum precipitation $(200 \mathrm{~mm})$ and minimum temperature $\left(-40^{\circ} \mathrm{C}\right)$, these two factors are limiting in relation to biomass and NPP, and the same phenomenon is typical for firs but differ for larches, pines and spruces. The development of such models for basic forest-forming species grown in Eurasia will give possibility to predict any changes in the biological productivity of forest cover of Eurasia in relation to climate change.

\section{References}

Anderson K.J., Allen A.P., Gillooly J.F. \& Brown J.H., 2006, Temperature-dependence of biomass accumulation rates during secondary succession. Ecology Letters 9: 673-682.

Baskerville G.L., 1972, Use of logarithmic regression in the estimation of plant biomass. Canadian Journal of Forest Research 2: 49-53.

Draper N. \& Smith H., 1966, Applied regression analysis. New York, Wiley. Translated under the title Prikladnoi regressionnyi analiz. "Statistika" Publishing, Moscow, $392 \mathrm{pp}$.

Esslen J., 1905, Das Gesetz des abnehmenden Bodenertrages seit Justus von Liebig: Eine dogmengeschichtliche Untersuchung. J. Schweitzer Verlag (Arthur Sellier), München, $290 \mathrm{pp}$.

Fang O., Yang Wang Y. \& Shao X., 2016, The effect of climate on the net primary productivity (NPP) of Pinus koraiensis in the Changbai Mountains over the past 50 years. Trees 30: 281-294.

Felton A., Nilsson U., Sonesson J., Felton A.M., Roberge J.-M., Ranius T., Ahlström M., Bergh J., Björkman C., Boberg J., Drössler L., Fahlvik N., Gong P., Holmström E., Keskitalo E.C., Klapwijk M.J., Laudon H., Lundmark T., Niklasson M., Nordin A., Pettersson M., Stenlid J., Sténs A. \& Wallertz K., 2016, Replacing monocultures with mixed-species stands: Ecosystem service implications of two production forest alternatives in Sweden. Ambio 45(Supplement 2): 124-139.

Givnish T.J., 2002, Adaptive significance of evergreen vs. deciduous leaves: Solving the triple paradox. Silva Fennica 36(3): 703-743.

Gower S.T. \& Richards J.H., 1990, Larches: Deciduous conifers in an evergreen world. BioScience 40(11): 818-826.

Gower S.T., McMurtrie R.E. \& Murty D., 1996, Aboveground net primary production decline with stand age: potential causes. Tree 11(9): 378-382.
Gower S.T., Krankina O., Olson R.J., Apps M., Linder S. \& Wang C., 2001, Net primary production and carbon allocation patterns of boreal forest ecosystems. Ecological Applications 11(5): 1395-1411.

He M., Yang B., Rossi S., Bräuning A., Shishov V. \& Kang Sh., 2019, Simulated and predicted responses of tree stem radial growth to climate change - A case study in semiarid north central China. Dendrochronologia 58: 125632.

Houghton R.A., Hall F. \& Goetz S.J., 2009, The importance of biomass in the global carbon cycle. Geophysical Research Letters 114: G00E03.

Huston M.A. \& Wolverton S., 2009, The global distribution of net primary production: resolving the paradox. Ecological Monographs 79: 343-377.

Kharuk V., Ranson K., Im S. \& Petrov I., 2015, Climateinduced larch growth response within the central Siberian permafrost zone. Environmental Research Letters 10(12):125009. doi: 10.1088/1748-9326/10/12/125009

Keeling H.C. \& Phillips O.L., 2007, The global relationship between forest productivity and biomass. Global Ecology and Biogeography 16: 618-631.

Laing J., \& Binyamin J., 2013, Climate change effect on winter temperature and precipitation of Yellowknife, Northwest Territories, Canada from 1943 to 2011. American Journal of Climate Change 2: 275-283.

Lapenis A., Shvidenko A., Shepaschenko D., Nilsson S. \& Aiyyer A., 2005, Acclimation of Russian forests to recent changes in climate. Global Change Biology 11: 2090-2102. doi: 10.1111/j.1365-2486.2005.01069.x

Levy P.E., Hale S.E. \& Nicoll B.C., 2004, Biomass expansion factors and root : shoot ratios for coniferous tree species in Great Britain. Forestry 77(5): 421-430. doi: 10.1093/forestry/77.5.421

Liebig Justus von, 1840, Die organische Chemie in ihrer Anwendung auf Agricultur und Physiologie. Braunschweig, Verlag Vieweg, [in:] Deutsches Textarchiv. http://www.deutschestextarchiv.de/liebig_agricultur_1840 [Accessed: 26.11.2019].

Liepa I.Ya., 1980, Dynamics of Wood Stock: Forecast and Ecology. Zinatne, Riga, 170 pp. (in Russian).

Lieth H., 1974, Modeling the primary productivity of the world. International Section for Ecology Bulletin 4: 11-20.

Magnani F., Mencuccini M. \& Grace J., 2000, Age-related decline in stand productivity: the role of structural acclimation under hydraulic constraints. Plant, Cell \& Environment 23: 251-263.

Molchanov A.A., 1971, Productivity of organic mass in the forests of different zones. "Nauka" Publishing House, Moscow, 275 pp. (in Russian).

Nemani R.R., Keeling C.D., Hashimoto H., Jolly W.M., Piper S.C., Tucker C.J., Myneni R.B. \& Running S.W., 2003, Climate-driven increases in global terrestrial net 
primary production from 1982 to 1999 . Science 300 (5625): 1560-1563.

Ni J., Zhang X.-S., \& Scurlock J.M.O., 2001, Synthesis and analysis of biomass and net primary productivity in Chinese forests. Annals of Forest Science 58: 351384.

Odum E.P., 1975, Fundamentals of Ecology. "Mir” Publishing, Moscow, 740 pp. (Translated from: E.P. Odum. Fundamentals of Ecology, The third ed. W.B. Saunders Company, Philadelphia-London-Toronto, 1971).

Rozenberg G.S., Ryansky F.N., Lazareva N.V., Saksonov S.V., Simonov Yu.V. \& Khasaev G.R., 2016, Common and Applied Ecology. Samara State University of Economics Press, Samara-Togliatti, 452 pp. (in Russian).

Shelford V.E., 1913, Animal communities in temperate America: as illustrated in the Chicago region; a study in animal ecology, Issue 5, Part 1. Pub. for the Geographic Society of Chicago by the University of Chicago Press, Chicago, 362 pp.

Stegen J.C., Swenson N.G., Enquist B.J., White E.P., Phillips O.L., Jorgensen P.M., Weiser M.D., Mendoza A.M. \& Vargas P.N., 2011, Variation in above-ground forest biomass across broad climatic gradients. Global Ecology and Biogeography 20: 744-754.

Taylor W.P., 1934, Significance of extreme or intermittent conditions in distribution of species and management of natural resources, with a restatement of Liebig's law of the minimum. Ecology 15: 274-379.

Usoltsev V.A., 2004, On the application of regression analysis in forestry problems. Lesnaya Taksatsiya i Lesoustroistvo (Forest Mensuration and Management) 1(33): 49-55 (in Russian).

Usoltsev V.A., 2007a, Biological productivity of Northern Eurasia's forests: Methods, datasets, applications. Ural State Forest Engineering University, Yekaterinburg, 636 pp. (Available at: http://elar.usfeu.ru/handle/123456789/3281).

Usoltsev V.A., 2007b, Some methodological and conceptual uncertainties in estimating the income component of the forest carbon cycle. Russian Journal of Ecology 38(1): 1-10. doi: 10.1134/S1067413607010018

Usoltsev V.A., 2010, Eurasian forest biomass and primary production data. Ural Branch of Russian Academy of Sciences, Yekaterinburg, 570 pp. (in Russian). (Available at: http://elar.usfeu.ru/handle/123456789/2606).

Usoltsev V.A., 2013, Forest biomass and primary production database for Eurasia: CD-version. The second ed., enlarged and re-harmonized. Ural State Forest
Engineering University, Yekaterinburg, (Available at: http://elar.usfeu.ru/bitstream/123456789/3059/4/Biomass $\% 20$ Database $\% 20-\% 20$ Eurasia.xls).

Usoltsev V.A., 2017, Foliage efficiency of forest-forming species in the climatic gradients of Eurasia. Sibirskij Lesnoj Zurnal (Siberian Journal of Forest Science) 4: 50-63 (in Russian with English abstract). doi: 10.15372/ SJFS20170405

Usoltsev V., 2019, Forest Arabesques, or Sketches of Our Trees' Life. The 3rd. Edition, modified. Radomska Szkoła Wyższa w Radomiu, Radom, Poland, 200 pp. doi: http://dx.doi.org/10.5281/zenodo.2551187

Usoltsev V.A., Shobairi S.O.R., Tsepordey I.S. \& Chasovskikh V.P., 2019a, Modelling forest stand biomass and net primary production with the focus on additive models sensitive to climate variables for two-needled pines in Eurasia. Journal of Climate Change 5(1): 41-49. doi: 10.3233/JCC190005

Usoltsev V.A., Merganičová K., Konôpka B., Osmirko A.A., Tsepordey I.S. \& Chasovskikh V.P., 2019b, Fir (Abies spp.) stand biomass additive model for Eurasia sensitive to winter temperature and annual precipitation. Central European Forestry Journal 65: 166-179. doi: 10.2478/forj-2019-0017

Usoltsev V., Piernik A., Osmirko A., Tsepordey I., Chasovskikh V. \& Zukow W., 2019c, Forest stand biomass of Picea spp.: an additive model that may be related to climate and civilisational changes. Bulletin of Geography. Socio-Economic Series 45: 133-147. doi: http:// dx.doi.org/10.1515/18860

Usoltsev V., Kovyazin V., Osmirko A., Tsepordey I. \& Chasovskikh V., 2019d, Additive model of Larix sp. forest stand biomass sensitive to temperature and precipitation variables in Eurasia. IOP Conference Series: Earth and Environmental Science 316: 1-9. 012074. doi:10.1088/1755-1315/316/1/012074.

Usoltsev V.A., Shobairi S.O.R., Osmirko A.A., Tsepordey I.S. \& Chasovskikh V.P., 2020, Susceptible Models to Climate Variables for Predicting the Stand Biomass and NPP of Larix spp in Eurasia. Systematics and Biodiversity (in press: TSAB-2019-0117).

Wang X., Fang J. \& Zhu B., 2008, Forest biomass and rootshoot allocation in northeast China. Forest Ecology and Management 255 (12): 4007-4020. DOI: 10.1016/j. foreco.2008.03.055

World Flora Online. http://www.worldfloraonline.org/

World Weather Maps, 2007. URL: https://www.mapsofworld.com/referrals/weather/ [Accessed: 15.06.2018]. 